\title{
REVISION OF THE GENUS CLEIDION (EUPHORBIACEAE) IN MALESIA
}

\author{
KRISTO K.M. KULJU \& PETER C. VAN WELZEN \\ Nationaal Herbarium Nederland, Universiteit Leiden branch, \\ P.O. Box 9514, 2300 RA Leiden, The Netherlands; \\ e-mail: kulju@nhn.leidenuniv.nl, welzen@nhn.leidenuniv.nl
}

SUMMARY

A revision of the Malesian species in the genus Cleidion is presented. Cleidion javanicum is shown to be the correct name for the widespread type species (instead of the name C. spiciflorum). A new species, $C$. luziae, resembling $C$. javanicum, is described from the Moluccas, New Guinea and the Solomon Islands. In addition, $C$. salomonis is synonymised with $C$. papuanum and $C$. lanceolatum is treated as a variety of $C$. ramosii. In total 7 Malesian Cleidion species are recognized. Cleidion megistophyllum from the Philippines cannot reliably be confirmed to belong to the genus due to lack of information and specimens and is treated as a doubtful species.

Key words: Cleidion, Acalypheae, Cleidiinae, revision, taxonomy, Malesia.

\section{INTRODUCTION}

Cleidion is a pantropical genus belonging to the large angiosperm family Euphorbiaceae s.s. It was described by Blume (1825), who included a single species $C$. javanicum ${ }^{1}$. The first revision was made by Müller Argoviensis $(1865,1866)$. His work was followed by the comprehensive treatment of Pax \& Hoffmann (1914), which included 17 species. Pax \& Hoffmann excluded the section Discocleidion Müll.Arg. which differs from Cleidion by the presence of a staminate and pistillate disc (in Cleidion a disc is absent), stipellate and palmatinerved leaves (in Cleidion the leaves are non-stipellate and pinnatinerved), and differences in anther type. Currently the genus Discocleidion (Müll.Arg.) Pax \& K. Hoffm. is considered as a member of the tribe Bernardieae, while Cleidion is placed in the tribe Acalypheae (Webster, 1994; Radcliffe-Smith, 2001).

All species of the genus Cleidion share a peculiar, unique anther type. The anthers are dorsifixed, the connective continuing as an inflexed apiculum. The anthers consist of 4 cells, with 2 superimposed cells at each side, which are confluent after opening introrsely in a cruciate manner (Fig. 2e). This special anther type does not occur in any other Euphorbiaceae genus. Additional typical (although not unique in the family) characters for the genus are the presence of extra-floral nectaries on both leaf surfaces and deeply split (bipartite) stigmas. Other features for Cleidion include: growth form shrub or tree; alternate, simple and penninerved leaves; petioles with an adaxial groove; axillary, racemiform or paniculate (or single-flowered when pistillate) inflorescences;

1) For the nomenclature of the type species, see note 1 under $C$. javanicum. 
small, pedicellate flowers without disc and petals; many anthers arranged in vertical series; mostly a 3-locular ovary; and capsulate, lobed fruits.

Cleidion is currently placed in the subtribe Cleidiinae (subfamily Acalyphoideae; tribe Acalypheae) with Sampantaea Airy Shaw and Wetria Baill. (Webster, 1994; Radcliffe-Smith, 2001). These two Asiatic genera, like Cleidion, have extra-floral nectaries on both leaf surfaces and deeply split stigmas. Radcliffe-Smith (2001) also mentions globose, vermiculate pollen as a unifying character for the subtribe. However, according to Takahashi et al. (2000), the tectum of Wetria pollen deviates from that of Cleidion and Sampantaea, resembling more genera from other subtribes (Adriana and Ricinus; subtribes Adrianinae and Ricininae, respectively). The monophyly of the subtribe is thus disputable. Also, the monophyly of Cleidion itself remains to be tested, although the unique anther type can be seen as a tentative synapomorphy for the genus.

Cleidion has an intriguing pantropical distribution. In addition to Malesia (7 species), the genus also occurs in continental Asia (5 additional spp.), Madagascar (1 sp.), West Africa (1 sp.), Central and South America (4 spp.), and the SW Pacific (15 spp.). Cleidion is remarkably diverse in New Caledonia with 12 endemic species (revised by McPherson \& Tirel, 1987).

In this paper we report a revision of the Malesian species of Cleidion. Non-Malesian material of these species was also examined, and a critical look was given to the other Cleidion species occurring in nearby areas. Seven species are recognised, of which one is described as new. Two species are synonymised, and one regarded as doubtful. In Malesia only one species, $C$. javanicum, is widespread and relatively common with more than 300 collections examined for this study. In contrast, four species are represented by $5-30$ collections, and three species by a single collection only.

\section{NOTES ON CHARACTERS AND MORPHOLOGY}

Descriptions and measurements are based solely on dry herbarium material and accompanying field notes. Colours presented indicate the fresh state inferred from field notes unless stated otherwise. The small organs were measured within a precision of $0.25 \mathrm{~mm}$ excluding anthers (precision $0.1 \mathrm{~mm}$ ). To describe leaf venation, the term 'nerve' is used for veins branching from the midrib (= secondary veins), and the terms 'veins' and 'veinlets' for the next two orders of venation (= tertiary and quaternary veins). The leaf nerve counts exclude the faint nerves at the apex. When measuring the staminate bud diameter, the frequently occurring premature buds were omitted, and only the largest buds were taken into account. The parts of pistillate inflorescences (excluding the ovary) do not considerably enlarge during fruit development, therefore, only a single measurement was taken.

Most of the Malesian Cleidion species are shrubs or small trees, only C. javanicum and $C$. luziae regularly exceed $10 \mathrm{~m}$ in height. Although the inferences made from herbarium collections and field notes are tentative, $C$. papuanum seems to have a deviating habit: a Schopfbaum-like unbranched or scantily branching shrub or treelet with the leaves grouped at the stem apices.

The distribution of the sexes is somewhat difficult to determine in Cleidion. Cleidion javanicum and $C$. papuanum are predominantly dioecious, although a few specimens have both staminate and pistillate inflorescences or aberrant bisexual inflorescences. 
The specimens of most of the other species can be both uni- or bisexual. This either indicates the occurrence of both uni- and bisexual individuals, or the separation (spatial and/or temporal) of two sexes within a plant.

\section{Indumentum and granules}

The indumentum in Malesian Cleidion consists of simple, short (rarely exceeding $0.5 \mathrm{~mm}$ in length) relatively stiff hairs. Most typically the hairs are sericeous (bent towards the apex of organs with an angle between $0^{\circ}$ and $45^{\circ}$ ), but hirsute (either strictly erect or variably oriented) hairs also occur. The density of the indumentum is roughly quantified by the terms glabrous, subglabrous (only a few occasional hairs), sparsely hairy and densely hairy (hairs covering most of the surface).

The surfaces of most Cleidion species are granulate, i.e., dotted with small round protuberances. This character is most clearly seen on the upper surface of relatively young leaves; on other plant surfaces (i.e., mainly young branches, stipules, bracts and sepals) granules can be variably indistinct or absent.

According to a preliminary anatomical study (data not shown), the granules on the leaf of $C$. ramosii are caused by large druses (star-shaped crystals) in the palisade parenchyma. Crystals can also occur in the leaves of the non-granulate species studied (C. javanicum), but they are too small to be seen as external protuberances. It is not known how well granulate surfaces can be seen in fresh plants, therefore, this character might be a drying artefact and thus only visible in dry herbarium material.

\section{Inflorescences}

The racemiform staminate inflorescences of Malesian Cleidion species consist of an unbranched rachis with a cluster of pedicellate flowers at each node (outside Malesia Cleidion can also have branching paniculate inflorescences). Four types can be distin-
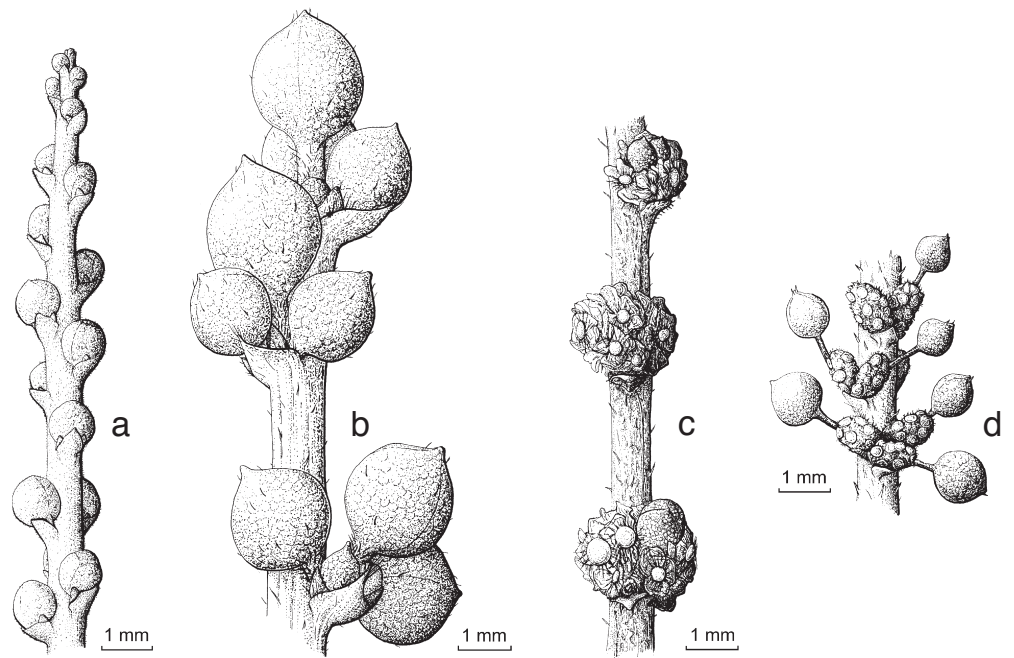

Fig. 1. Different types of flower clusters in staminate inflorescences of Cleidion. a. C. luziae Kulju with only one flower per node; b. fasciculate cluster of $C$. javanicum Blume; c. glomerulate cluster of $C$. moniliflorum Airy Shaw; d. branched and slightly elongated clusters of $C$. papuanum Lauterb. (a: Kajewski 2305, A; b: PNH 17379, A; c: NGF 27334, K; d: BSIP 7184, L). 
guished on the basis of the flower production capacity and the structure of the flower clusters (Fig. 1). A few species (C. luziae and Vietnamese C. bracteosum) have true racemes with only one flower per node. In some other species (e.g., C. javanicum), the node produces several flowers, resulting in a fasciculate cluster (individual flowers and pedicels still being separate). If flower production continues for a longer period, a dense, glomerulate cluster develops, consisting largely of bracteoles and pedicels of fallen flowers. In the fourth type, seen in C. papuanum, the cluster is branched and slightly elongated in form. When using the cluster types for species identification, it is important to realise that the glomerulate and elongated clusters form over time and, therefore, can still look fasciculate in younger inflorescences.

Most Malesian species have racemiform pistillate inflorescences with each node producing one, or sometimes two or three, flowers. However, quite often, some of the bracts remain sterile. The strictly single-flowered inflorescences of $C$. javanicum and C. luziae can thus be regarded as a further reduction, in which only one flower develops. Cleidion luziae has a somewhat intermediate inflorescences with persistent bracts and, usually, an abscission zone in the terminal pedicel, whereas in C. javanicum bracts are early caducous and the abscission zone is absent. The reduction in the number of flowers is associated in these two species with the increase in the size of the seeds, presumably indicating a shift in reproduction strategy.

\section{CLEIDION}

Cleidion Blume (1825) 612; Müll.Arg. (1865) 183; (1866) 983; Pax \& K. Hoffm. (1914) 288; (1931) 127; Backer \& Bakh.f. (1964) 487; Airy Shaw (1972) 234; Whitmore (1973) 79; Airy Shaw (1975) 74; (1980c) 57; (1981) 279; (1982) 12; (1983) 13; McPherson \& Tirel (1987) 143; G.L. Webster (1994) 86; Govaerts, Frodin \& Radcl.-Sm. (2000) 356; Radcl.-Sm. (2001) 211. - Type: Cleidion javanicum Blume.

Psilostachys Turcz. (1843) 58. - Type: Psilostachys axillaris Turcz. [= Cleidion tricoccum (Casar.) Baill., vide Radcl.-Sm. (2001) 212].

Redia Casar. (1843) 51. - Type: Redia tricocca Casar. [= Cleidion tricoccum (Casar.) Baill., vide Radcl.-Sm. (2001) 212].

Lasiostyles C. Presl (1845) 579. - Type: Lasiostyles salicifolia C. Presl [= Cleidion javanicum Blume].

Tetraglossa Bedd. (1861) 70. - Type: Tetraglossa indica Bedd. [= Cleidion javanicum Blume].

Shrubs to trees; mono- or dioecious; very young branches somewhat angular when dry, older branches terete, glabrescent. Indumentum consisting of simple, short hairs, sericeous (to hirsute with erect or variably oriented hairs), most parts glabrous to only sparsely hairy (the inside of organs always (sub) glabrous); granulate surfaces absent to present. Stipules triangular, usually caducous, base and central part thickened, margin entire and sometimes hairy, apex acute. Leaves alternate, simple; petiole with adaxial groove, usually basally and apically pulvinate, sometimes with 2 raised glands at apex; blade (ovate to) elliptic to obovate, symmetric, papery (to somewhat coriaceous in C. papuanum), margin subentire to crenate to serrate (tooth size varying within a species), with a gland in each tooth, apex usually acuminate; both surfaces with small roundish extra-floral nectaries (= macular glands; in $C$. moniliflorum only on lower surface), on upper surface mainly grouped loosely near the base, on lower surface mainly in the basal half of the blade and often more or less in lengthwise rows; upper surface 
usually darker green than lower surface; venation pinnate, \pm flat above, raised beneath, nerves looped and closed near the margin, veins (irregularly) scalariform to reticulate, veinlets reticulate. Inflorescences axillary, single (or in C. moniliflorum the staminate ones ramiflorous and often 2 together), unisexual, racemiform (to paniculate outside Malesia) in both sexes to single-flowered when pistillate, rachis often with longitudinal ridges when dry, staminate nodes with 1 flower only or bearing several flowers in a fasciculate to glomerulate (to slightly elongated and branched) cluster, pistillate nodes with 1-3 flowers (or sometimes remaining sterile); bracts triangular to ovate, base and central part thickened, margin entire, often hairy, apex acute (to acuminate when staminate), staminate ones persistent, pistillate ones caducous to persistent; bracteoles resembling bracts but smaller, pistillate ones in pairs at the base of the pedicel (absent when inflorescence single-flowered). Flowers actinomorphic, pedicellate; sepals free; petals and disc absent. Staminate flowers: pedicel with an abscission zone in the middle part; buds broadly ovoid, apiculate; sepals ( 2 or) 3 (or 4), ovate, valvate, apex acute, mucronulate; receptacle somewhat swollen; stamens 40-120 (in Malesia), filaments flattened, glabrous, anther dorsifixed, 4-celled, on both sides 2 cells above each other, opening introrsely and cruciately, connective often darker in colour, apiculate; pistillode absent. Pistillate flowers: pedicel with abscission zone (absent in C. spiciflorum), widening towards the apex; buds elongated; sepals $3-5$, ovate to triangular, imbricate, base and central part thickened, margin entire, often hairy, apex acute, usually persistent; ovary 2- or 3- (or 4-)locular; 1 ovule per locule; style often very short to absent; stigmas deeply split, upper surface papillose. Fruits lobed capsules, opening septicidally and (sometimes incompletely) loculicidally, inner wall usually with shallow depressions; column with a broadened apex. Seeds subglobose, \pm smooth, straw to brown when dry, usually mottled, testa not fleshy, caruncle absent.

Distribution - Pantropical (c. 33 spp.), most diverse in Asia and the South West Pacific. Seven species in Malesia.

\section{KEY TO THE MALESIAN SPECIES}

\section{Notes}

1) Use at least a hand lens, or preferably a dissecting microscope. Necessary for observing indumentum, granulate surfaces (especially on staminate buds) and extra-floral nectaries.

2) Due to missing information, the doubtful species Cleidion megistophyllum (Quisumb. $\&$ Merr.) Airy Shaw is excluded from the key. This Philippine species differs from all other Cleidion species in its exceptionally large, obovate leaves (blade 115-155 $\mathrm{cm}$ long) and large seeds (17-19 by $17-19 \mathrm{~mm}$ ).

1a. Domatia present in nerve axils of lower leaf surface. Pistillate inflorescences always single-flowered. Ovary 2- (or 3-)locular, bipartite stigmas 2 (or 3). Fruits with 1 or 2 (very rarely 3 ) seeds, $11-18 \mathrm{~mm}$ long $\ldots \ldots \ldots \ldots \ldots \ldots$ 1. C. javanicum

b. Domatia absent in nerve axils of lower leaf surface. Pistillate inflorescences single-flowered or racemiform with several flowers. Ovary 3- (or 4-)locular, bipartite stigmas 3 (or 4). Fruits mostly with 3 seeds, $4-10 \mathrm{~mm}$ long (unknown for C. minahassae and $C$. moniliflorum) ........................ 2 
2a. Youngest internodes, petioles and midrib at leaf lower surface glabrous. Leaf upper surface not granulate (dry material). Staminate flowers 1 per node. Pistillate inflorescences always 1-flowered, 3.5-6 cm long. Style 1.5-5 mm long. Seeds $7-7.5$ by $7-8 \mathrm{~mm} . \ldots \ldots \ldots \ldots \ldots \ldots \ldots \ldots \ldots \ldots \ldots$. C. luziae

b. Youngest internodes, petioles and midrib at leaf lower surface (subglabrous to) hairy. Leaf upper surface (sometimes indistinctly) granulate (dry material). Staminate flowers several to many per node. Pistillate inflorescences 1-16-flowered, 4.5-45 $\mathrm{cm}$ long. Style $0-1.5 \mathrm{~mm}$ long (unknown for $C$. moniliflorum). Seeds $3-6$ by $3.5-5$

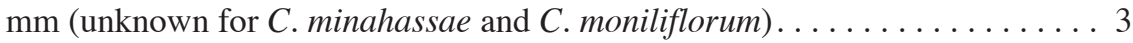

3a. All leaves clearly obovate, petiole $0.4-2.5 \mathrm{~cm}$ long, blade $9.8-73 \mathrm{~cm}$ long, base gradually narrowing, cuneate (to attenuate). Staminate flowers many per node, in glomerulate or often slightly elongated, branching clusters. - New Guinea, Solomon Islands. . . . . . . . . papuanum

b. Leaves (ovate to) elliptic (to only some of the leaves slightly obovate), petiole $0.5-8 \mathrm{~cm}$ long, blade $6.6-23 \mathrm{~cm}$ long, base shortly narrowing, rounded to acute to cuneate to attenuate. Staminate flowers several to many per node, in fasciculate or glomerulate, non-branching clusters. - Philippines, Sulawesi, New Guinea (New

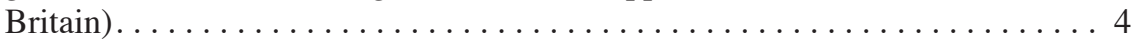

4a. Leaf upper surface without extra-floral nectaries. Staminate inflorescences ramiflorous, often 2 together, up to $50 \mathrm{~cm}$ long. - New Britain. 5. C. moniliflorum

b. Leaf upper surface with extra-floral nectaries. Staminate inflorescences axillary, single, up to $15(-24) \mathrm{cm}$ long. - Philippines, Sulawesi . . . . . . . . . . . 5

5a. Staminate buds granulate. Pistillate inflorescence with nodes only in upper half (counting also sterile nodes with bracts only). Abscission zone at basal part of pistillate pedicel (1-9 mm from base). — Philippines . . . . . . . . 7. C. ramosii

b. Staminate buds without a distinctly granulate surface. Pistillate inflorescence with nodes also in basal half. Abscission zone at middle to apical part of pistillate pedicel (5-23 mm from base). - Philippines, Sulawesi . . . . . . . . . . . 6

6a. Leaf petiole $0.8-2.5 \mathrm{~cm}$ long; blade $6.6-15$ by $2.4-6.5 \mathrm{~cm}$; margin subentire to crenate (to serrate); nerves 6-9 per side. Staminate inflorescences up to $7 \mathrm{~cm}$ long, flowers in fasciculate clusters. Stamens 50-58. Pistillate inflorescences with 1-5

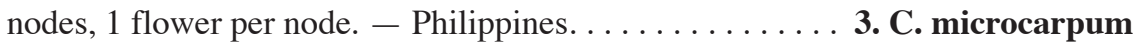

b. Leaf petiole $1.5-6.5 \mathrm{~cm}$ long; blade $7.5-23$ by $3.6-10.8 \mathrm{~cm}$; margin serrate; nerves 9-13 per side. Staminate inflorescences up to $15 \mathrm{~cm}$ long, flowers in glomerulate clusters. Stamens 78-99. Pistillate inflorescences with 2-14 nodes, 1 or 2 flowers per node. - Sulawesi ................. 4. C. minahassae

\section{Cleidion javanicum Blume - Fig. 2; Map 1}

Cleidion javanicum Blume (1825) 613; Kurz (1877) 390; Hook.f. (1885) 444; Brandis (1906) 592; Cooke (1906) 618; Talbot (1911) 488; Pax \& K. Hoffm. (1914) 290; Gagnep. (1926) 450; Kanjilal, P.C. Kanjilal, R.N. De \& A. Das (1940) 220; Backer \& Bakh.f. (1964) 487; Prain (1963) 712; Airy Shaw (1975) 74; (1980c) 57; (1981) 279; (1982) 12; H.S. Kiu, S.M. Hwang \& Y.T. Chang (1996) 75. - Lectotype (selected here): Blume (Anonymous) s.n. '1336' (holo L, barcode L 0270644), Java, in monte Bonkok Provinciae Tjanjor.

Lasiostyles salicifolia C. Presl (1845) 579. - Type: Helfer 221 (n.v.), Martaban.

Rottlera urandra Dalzell (1851) 229; Dalzell \& A. Gibson (1861) 230. - Type: Dalzell s.n. (K), in jugo Syhadrensi, prope Phondaghat. 
Tetraglossa indica Bedd. (1861) 70. - Type: Beddome? (n.v.).

Macaranga tamiana K. Schum. (1895) 52. - Type: Bammler 4 (n.v.), New Guinea, Kaiser Wilhelmsland, Tami Isl.

Cleidion spiciflorum auct. non (Burm.f.) Merr. (excl. type): Merr. (1917) 322, in obs.; (1923) 439; Airy Shaw (1972) 234; Whitmore (1973) 79; Airy Shaw (1980b) 607; (1983) 13; Grierson \& D. G. Long (1987) 803; Philcox (1997) 167. See note 1.

(Shrub to) tree, up to $30 \mathrm{~m}$ high, dbh up to $50 \mathrm{~cm}$, dioecious (to rarely monoecious); flowering branches $1-4.5 \mathrm{~mm}$ thick. Outer bark smooth to slightly roughened or fissured, thin, grey to brown (to greenish), cream to yellow inside, inner bark 3-10(-20) mm thick, light brown to yellowish to straw; sapwood white to straw to creamy yellow. Indumentum sericeous, in staminate parts also hirsute and variably oriented, vegetative parts (excluding domatia) glabrous, generative parts (sub)glabrous to sparsely hairy (except ovary glabrous to densely hairy); granulate surfaces absent. Stipules $2-3.5$ by $0.75-1.5 \mathrm{~mm}$, early caducous. Leaves usually in Terminalia growth (flushes); petiole $0.9-9 \mathrm{~cm}$ long, usually with 2 raised glands at apex; blade (ovate to) elliptic (to slightly obovate), $5-24$ by $1.7-9.7 \mathrm{~cm}$, length/width ratio $1.7-3.8(-4.6)$, base obtuse to cuneate (to attenuate), margin subentire to serrate with coarse teeth, teeth 7-20 per side, apex (rounded to acute to) acuminate, very apex retuse to rounded to acute, lower surface with shallow, open domatia with single and tufted hairs; nerves (3-)4-10 per side. Staminate inflorescences up to $25 \mathrm{~cm}$ long, basally $0.5-1.5 \mathrm{~mm}$ thick, flowers $3-\mathrm{sev}-$ eral per node, in fascicles, rachis green; bracts $1-2.5$ by 1-2 mm. Staminate flowers: pedicels up to $7 \mathrm{~mm}$ long, light green; buds $1.5-3 \mathrm{~mm}$ diam., brown when dry; sepals $2-4$ by $1-2.5 \mathrm{~mm}$, (light) green; stamens $48-120$, filaments up to $1.8 \mathrm{~mm}$ long, anthers (0.3-) $0.4-0.6$ by $0.3-0.6(-0.8) \mathrm{mm}$, yellow to cream, apiculum $0.1-0.3 \mathrm{~mm}$ long. Pistillate inflorescences $2.5-11.5 \mathrm{~cm}$ long, basally $0.75-1.5 \mathrm{~mm}$ thick, 1-flowered, with $1-4$ sterile bracts; latter $1.5-2$ by $0.75-2 \mathrm{~mm}$, early caducous. Pistillate flowers: abscission zone absent; sepals ( 4 or) $5,1-2.5$ by $1-2 \mathrm{~mm}$, green, caducous to persistent; locules 2 (or 3); style 1-12 mm long; stigmas erect, 15-30 mm long. Fruits: one locule often reduced (perfect 3 -seeded fruits extremely rare), 11-18 by 13-21 (1-seeded) or 19-28 mm (2-seeded), tardily opening, surface \pm smooth to verrucose, green when fresh, dark brown to dark grey when dry, inner wall often mottled. Seeds 8.5-14 by $8.5-13.5 \mathrm{~mm}$; hilum elliptic to obovate, $2.5-5.5$ by $1-2.5 \mathrm{~mm}$.

Distribution - From India and Sri Lanka through SE Asia mainland to S China and Indochina, throughout Malesia (absent in the Moluccas) to Australia (Queensland), the Solomon Islands and Vanuatu.

Habitat \& Ecology - In open to shaded places, evergreen to deciduous primary and secondary forests, often along rivers or streams; alluvial to dry soil; varying bedrock, but often on limestone. Altitude up to $1200 \mathrm{~m}$. Flowering and fruiting: Thailand: January to March (fl), April to August (fr); Sumatra \& Borneo: March to August (fl $\&$ fr); Java: August to December (fl \& fr); Philippines: January to April (fl), April to September (fr).

Vernacular names - Thailand: Di mee (Kariëng); dimi, ma-dee-mee, maj maduug. Sumatra: Urel tenge. Borneo: Entupak (Iban). Java: Hura batu (Sundanese). Bali: Putian (Javanese). Philippines: Paitan, santiki (Tagalog); tubataba (Tagbanua). Papua New Guinea: Tea (Bembi); marramamoi (Kaigulin); la mala goli goli (West Nakanai, New Britain); siwono, ibubu (Bougainville Isl.). Solomon Islands: Saola (Kwara'ae). Vanuatu: Doptop wumer (Uripiv, Malekula Isl.); nagheliromp (Larevet, Malekula Isl.). 


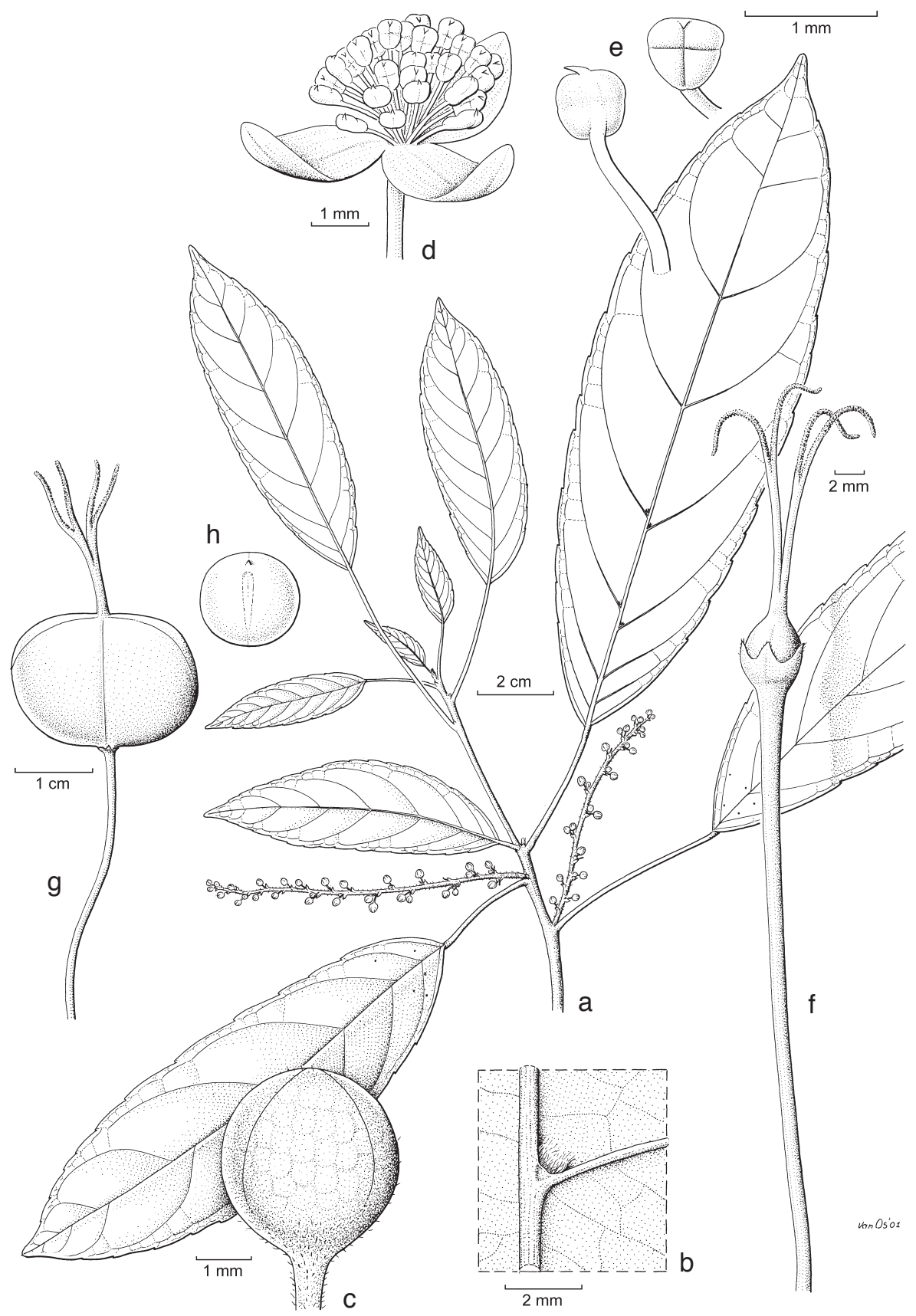

Fig. 2. Cleidion javanicum Blume. a. Habit of staminate plant; b. detail of domatia at lower leaf surface; c. detail of staminate bud; d. detail of open staminate flower; e. details of stamen; f. detail of pistillate flower; g. detail of fruit; h. detail of seed (a, c-e: Kerr 10298; b: NGF 39145; f: Maxwell 75-91; g: Maxwell 89-538; h: Maxwell 88-755; all L). 


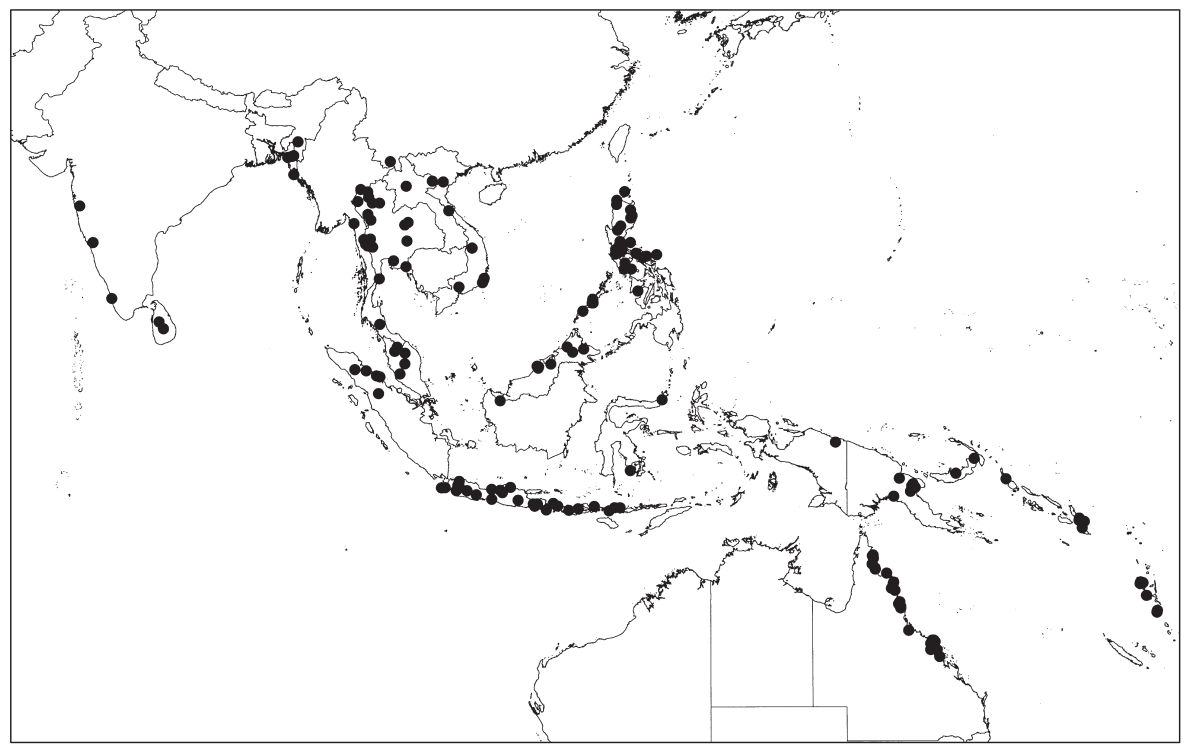

Map 1. Distribution of Cleidion javanicum Blume.

Uses - Various parts are used medicinally in Thailand and the Philippines: a decoction of the poisonous leaves will produce abortion, and a decoction of the bark is used for stomach ache (Quisumbing, 1978); in the Solomon Islands a decoction of the bark is used externally to treat scabies (Henderson \& Hancock, 1988). It is a common village shade tree in the Solomon Islands (Henderson \& Hancock, 1988). The wood is used for house posts in Vanuatu. The wood is reported to be greyish white and soft (Burkill, 1966).

Notes -1 . The two epithets javanicum and spiciflorum have been inconsistently used for this species after Merrill (1917) interpreted the type of Acalypha spiciflora Burm.f. as belonging to it. This interpretation was based on the figure of Burman's type in Flora Indica (Burman, 1768: 203). Later, in his annotation of the actual type in the Delessert Herbarium (G), Merrill identifies the type as a species of Claoxylon and not at all as Cleidion. Cleidion javanicum is thus the correct name for the species.

2. Part of continental Asian material is excluded here from $C$. javanicum and tentatively placed to the closely resembling species $C$. alongense Bennet \& Subh. Chandra (type n.v.). This taxon is characterized by on average larger leaves with coarser teeth, densely hairy staminate rachises, 3-locular ovaries and 3-seeded fruits. It also seems to be mostly geographically apart from $C$. javanicum, occurring in mountainous areas at NE India, Nepal, Bhutan, China (Yunnan) and northern Burma. With this circumscription C. javanicum has almost exclusively 2-locular ovaries and 1- or 2-seeded fruits (only two specimens seen with perfect 3-seeded fruits).

Diagnostic characters - The only Malesian species with domatia on lower leaf surface and a predominantly 2-locular ovary. 
2. Cleidion luziae Kulju, spec. nov. - Fig. 3; Map 2

Arbor. Partes vegetativae stipulis exclusis glabrae. Granula desunt. Folia papyracea (ovata ad) elliptica indice 2.3-3.4 sine domatiis. Inflorescentiae staminatae aliquot floribus ad nodos solitariis; pistillatae bracteis sterilibus 2-5 persistentibus uniflorae, pedicello plerumque articulato. Ovarium 3-loculare. Semina 7-7.5 mm longa 7-8 mm lata. - Typus: Kajewski 2305 (holo A; iso BM, BRI), Papua New Guinea, Bougainville, Karngu, Buin.

(Small) tree, up to $15 \mathrm{~m}$ high, presumably monoecious; flowering branches $1.5-2 \mathrm{~mm}$ thick. Bark smooth, grey to brown. Indumentum sericeous, in staminate parts also hirsute and variably oriented, vegetative parts glabrous (to sparsely hairy on stipules outside), generative parts (sub)glabrous to sparsely hairy (ovary densely hairy); granulate surfaces absent. Stipules $1.5-3$ by $0.75-1 \mathrm{~mm}$, caducous (to persistent). Leaves inserted evenly along branches or in Terminalia-growth; petiole $0.8-4.6 \mathrm{~mm}$ long, sometimes with 2 raised glands at apex; blade (ovate to) elliptic, $8-20$ by $2.7-7.3 \mathrm{~cm}$, length/width ratio $2.4-3.4$, base rounded to acute, margin subentire to finely serrate, teeth 3-14 per side, apex acuminate, very apex acute, lower surface without domatia; nerves 6-9 per side. Staminate inflorescences: only small fragments seen, basally c. $0.5 \mathrm{~mm}$ thick, flowers 1 per node; bracts $0.25-0.5$ by $0.2-0.5 \mathrm{~mm}$. Staminate flowers: buds $1.25-1.5$ mm diam., brown when dry; sepals c. 1.75 by $1 \mathrm{~mm}$; stamens 59-76, filaments up to c. $1 \mathrm{~mm}$ long, anthers $0.3-0.4$ by $0.4-0.5 \mathrm{~mm}$, apiculum c. $0.1 \mathrm{~mm}$ long. Pistillate inflorescences $3.5-6 \mathrm{~cm}$ long, basally $0.5-1 \mathrm{~mm}$ thick, 1 -flowered, with $2-5$ sterile bracts; latter $1-2.5$ by $0.5-1.25 \mathrm{~mm}$, persistent. Pistillate flowers: pedicel usually with abscission zone; sepals ( 3 or) 4 or $5,1-2$ by $0.75-1.5 \mathrm{~mm}$, persistent; locules 3 ; style $1.5-5 \mathrm{~mm}$ long; stigmas erect, $13-24 \mathrm{~mm}$ long. Fruits usually 3 -seeded, $8-10$ by 13-16 mm, \pm smooth, brown when dry. Seeds $7-7.5$ by $7-8 \mathrm{~mm}$; hilum subcircular, somewhat raised, $1-1.5$ by c. $1 \mathrm{~mm}$.

Distribution - Moluccas (Buru, Seram), New Guinea, Solomon Islands.

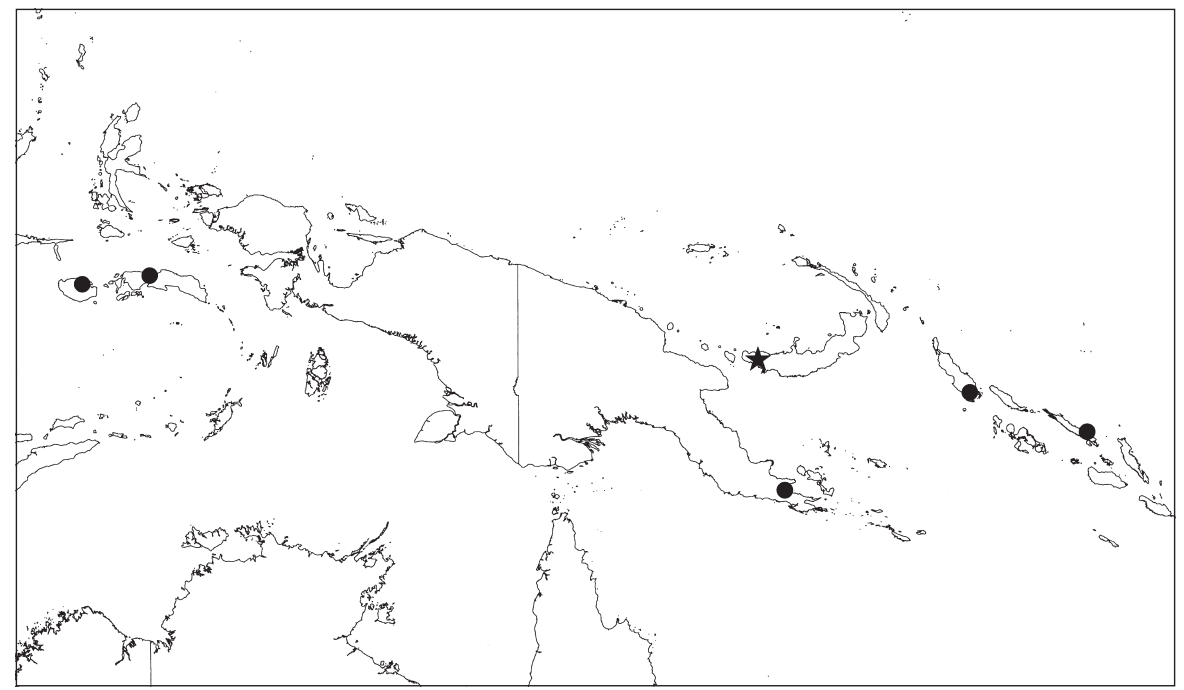

Map 2. Distribution of Cleidion luziae Kulju $(\bullet)$ and C. moniliflorum Airy Shaw ( $\star$ ). 


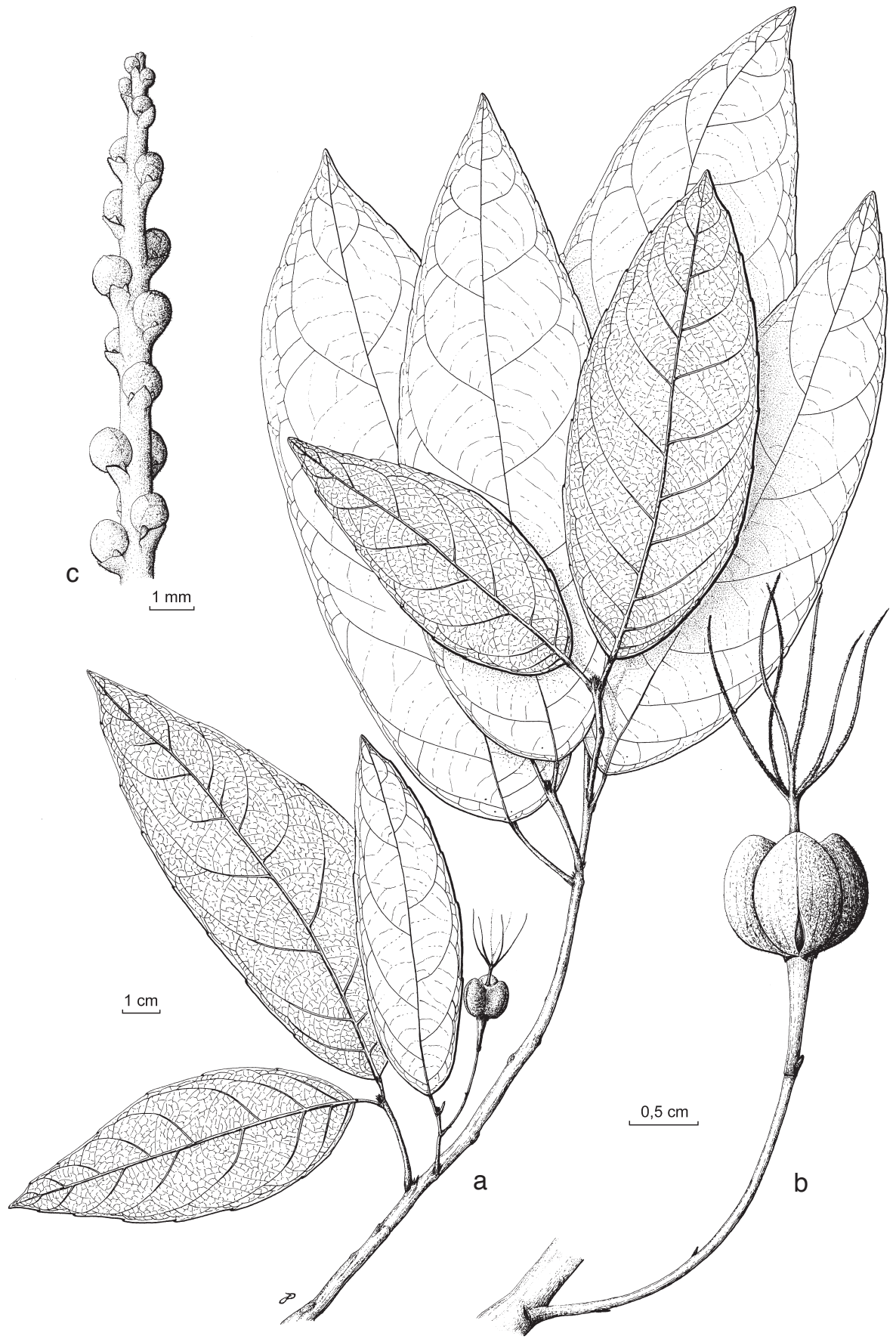

Fig. 3. Cleidion luziae Kulju. a. Habit of pistillate plant; b. detail of infructescence; c. detail of staminate inflorescence (a-c: Kajewski 2305, A). 
Habitat \& Ecology — Forests, often on limestone. Altitude up to $1000 \mathrm{~m}$. Flowering and fruiting: mainly September to December.

Vernacular names - Moluccas: Ai batu, buah hijau muda, daun panjang lancip, perbukitan, tumbuh banyak di batu-batu/jurung (Seram Isl.). Papua New Guinea: Numarrie (Bougainville).

Uses - The fruits are eaten with betel nut to relieve colds (Bougainville).

Note - This new species, represented by 5 specimens, resembles $C$. javanicum, but lacks domatia and has single-flowered staminate nodes, persistent pistillate bracts, always 3-locular ovaries and smaller seeds. In addition, the pistillate pedicels of C. luziae usually have an abscission zone. Vietnamese C. bracteosum Gagnep. also has staminate inflorescences with single-flowered nodes, but this species differs from C. luziae in having broader, subcoriaceous leaves and much longer staminate bracts.

\section{Cleidion microcarpum Merr. - Fig. 4; Map 3}

Cleidion microcarpum Merr. (1926) 404. - Type: BS (Ramos \& Edaño) 44226 (holo UC; iso A, B, K, US), Philippines, Sulu Archipelago, Tawi Tawi.

Shrub to small tree, up to 5(-10) $\mathrm{m}$ high, dbh up to $10 \mathrm{~cm}$, mono- or dioecious; flowering branches 1-1.5 mm (staminate) or 1.5-2 mm (pistillate) thick. Bark grey, slightly roughened. Indumentum sericeous, vegetative parts (subglabrous to) sparsely hairy (except leaf blade), generative parts (subglabrous to) sparsely hairy (ovary densely hairy); granulate surfaces present. Stipules $2.5-3.5$ by $0.75-1.25 \mathrm{~mm}$, early caducous. Leaves inserted evenly along branches; petiole $0.8-2.5 \mathrm{~cm}$ long, apical glands absent; blade elliptic (to some slightly obovate), $6.6-15$ by $2.4-6.5 \mathrm{~cm}$, length/width ratio

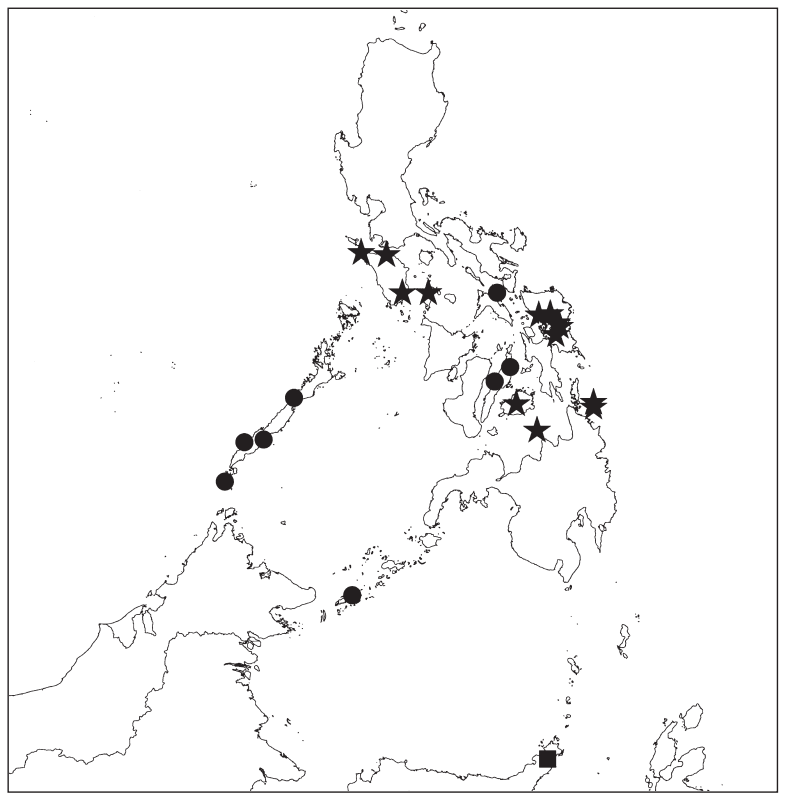

Map 3. Distribution of Cleidion microcarpum Merr. (๑), C. ramosii (Merr.) Merr. ( $\star$ ) and C. minahassae Pax \& K. Hoffm. 


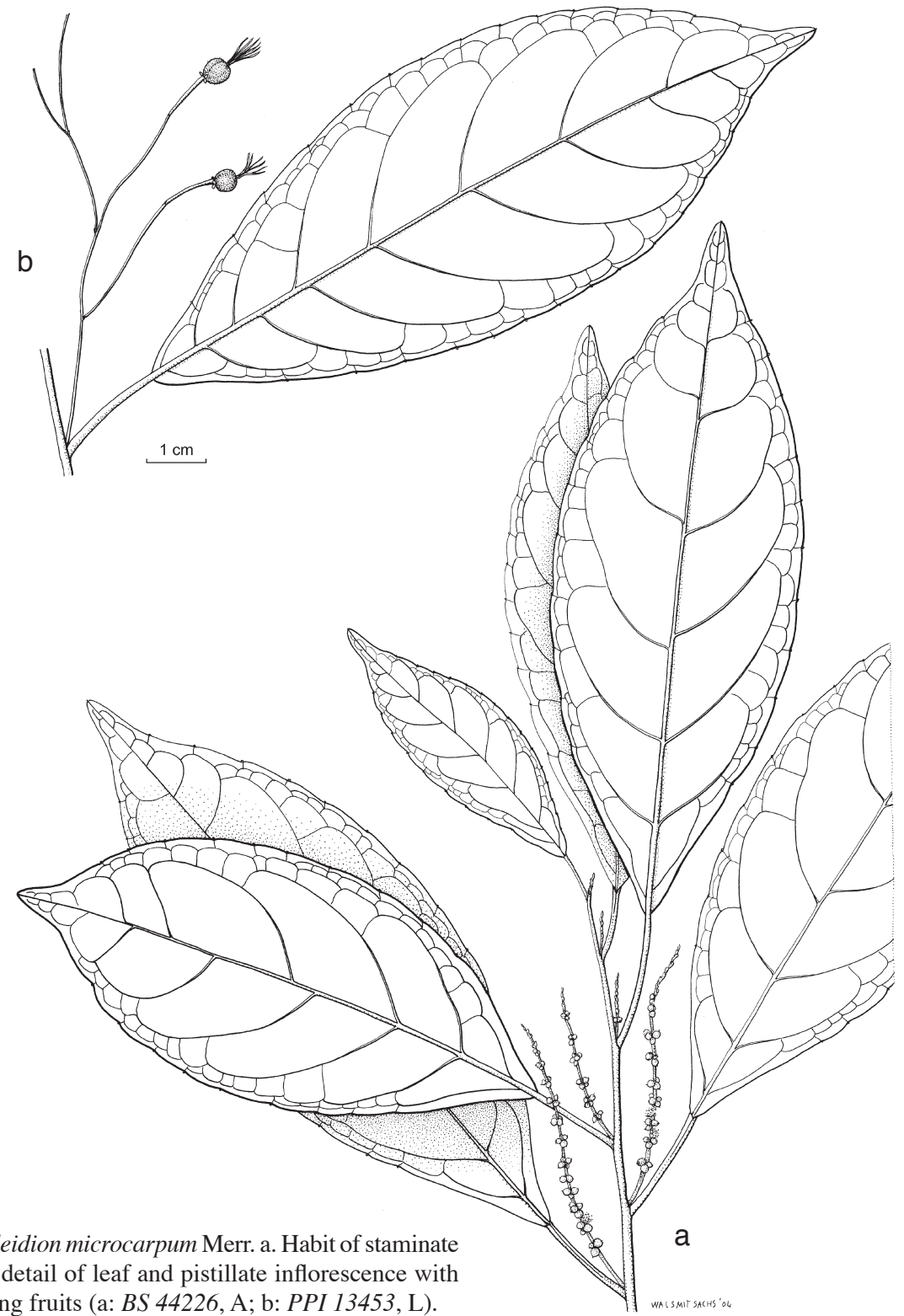

Fig. 4. Cleidion microcarpum Merr. a. Habit of staminate plant; b. detail of leaf and pistillate inflorescence with developing fruits (a: BS 44226, A; b: PPI 13453, L).

$2-2.8(-3.5)$, base acute to cuneate to slightly attenuate, margin subentire to crenate (to serrate), teeth 8-16 per side, apex (rounded to) acuminate, very apex (truncate to) rounded, upper surface (sub)glabrous, lower surface (subglabrous to) sparsely hairy only on midrib and nerves, domatia absent; nerves 6-9 per side. Staminate inflorescences up to $7 \mathrm{~cm}$ long, basally $0.5-0.75 \mathrm{~mm}$ thick, flowers several per node, in fascicles; bracts $0.75-1$ by $0.75-1 \mathrm{~mm}$. Staminate flowers: pedicels up to $1 \mathrm{~mm}$ long; buds $1-1.5 \mathrm{~mm}$ 
diam., light brown when dry, without a distinctly granulate surface; sepals $1.5-2$ by $1-1.5 \mathrm{~mm}$; stamens $50-58$, filaments up to $0.75 \mathrm{~mm}$ long, anthers $0.3-0.4$ by $0.4-0.6$ $\mathrm{mm}$, apiculum less than $0.1 \mathrm{~mm}$ long. Pistillate inflorescences $4.5-11 \mathrm{~cm}$ long, basally $0.5-0.75 \mathrm{~mm}$ thick, with $1-5$ nodes also in basal half, 1 flower per node; bracts $0.75-1$ by $0.75-1 \mathrm{~mm}$, persistent. Pistillate flowers: pedicel $20-35 \mathrm{~mm}$ long, with abscission zone in middle to apical part (7-23 mm from base); sepals $3,1-1.5$ by $0.5-1 \mathrm{~mm}$, without distinctly granulate surface, persistent; locules 3 ; style c. $0.25 \mathrm{~mm}$ long; stigmas erect, $3-8 \mathrm{~mm}$ long. Fruits $5-6$ by c. $8 \mathrm{~mm}$, readily opening, \pm smooth, brown when dry. Seeds $3.5-4$ by $3.5-4$; hilum \pm elliptic, $0.5-0.75$ by $0.1-0.25 \mathrm{~mm}$.

Distribution - Philippines (Palawan, Balabac, Ticao, Cebu, Tawi Tawi).

Habitat \& Ecology - (Disturbed and secondary) forests, often on limestone. Altitude up to $670 \mathrm{~m}$. Flowering and fruiting: mainly May to October.

Vernacular names - Philippines: Piligaw-bukid, sarum puti, yambon-yambon (Tagbanua).

Diagnostic characters - This species may be difficult to distinguish vegetatively from C. ramosii var. ramosii, which also occurs in the Philippines. Although the measurements of these species overlap, $C$. microcarpum tends to have shorter petioles and smaller leaves with a mainly crenate (as opposed to a mainly serrate) margin.

\section{Cleidion minahassae Pax \& K. Hoffm. - Fig 5; Map 3}

Cleidion minahassae Pax \& K. Hoffm. (1919) 23; Airy Shaw (1982) 12. - Type: Warburg 15544 $(\mathrm{B} \dagger)$, Celebes, Minahassa. Neotype (selected here): Forsten 11 (holo L, barcode 0158342; iso L, barcodes 0158343, 0158346, 0158349), Celebes, in sylvis Tondano.

Tree; flowering branches 2-4 $\mathrm{mm}$ (staminate) or 1.5-2 $\mathrm{mm}$ (pistillate) thick. Indumentum sericeous, vegetative parts (subglabrous to) sparsely hairy (except leaf blade), generative parts (subglabrous to) sparsely hairy (ovary densely hairy); granulate surfaces present. Stipules $3-5$ by $1.5-2$, caducous to somewhat persistent. Leaves inserted evenly along branches; petiole $1.5-6.5 \mathrm{~cm}$ long, apical glands absent; blade elliptic to some slightly obovate, $7.5-23$ by $3.6-10.8 \mathrm{~cm}$, length/width ratio $2.1-2.9$, base acute to cuneate to slightly attenuate, margin serrate, teeth $12-24$ per side, apex acuminate, very apex truncate to acute, upper surface (sub) glabrous, lower surface sparsely hairy only on midrib and nerves, domatia absent; nerves 9-13 per side. Staminate inflorescences up to $15 \mathrm{~cm}$ long, basally $1-1.5 \mathrm{~mm}$ thick, flowers many per node, in glomerules; bracts c. 1 by $1 \mathrm{~mm}$. Staminate flowers: mature flowers not seen; buds dark brown when dry, without a distinctly granulate surface; stamens 78-99. Pistillate inflorescences 10-14 cm long, basally $0.75-1.25 \mathrm{~mm}$ thick, with 2-14 nodes also in basal half, 1 or 2 flowers per node; bracts c. 1.25 by $1 \mathrm{~mm}$, persistent. Pistillate flowers: pedicel 7-30 mm long, with abscission zone in middle to apical part (5-20 $\mathrm{mm}$ from base); sepals 3 or $4,1.5-2$ by $0.5-1 \mathrm{~mm}$, without distinctly granulate surface, persistent; locules 3 ; style $0.25-0.5 \mathrm{~mm}$ long; stigmas erect, 6-8 mm long. Fruits and seeds not seen.

Distribution - Indonesia: north-eastern Sulawesi.

Habitat \& Ecology - Unknown.

Note - The original type (Warburg 15544) in B has been destroyed. The description here is based on four sheets at L (Forsten 11, Tondano). These sheets, presumably representing a single collection, match the original diagnosis in most parts well and are here designated as a neotype. 


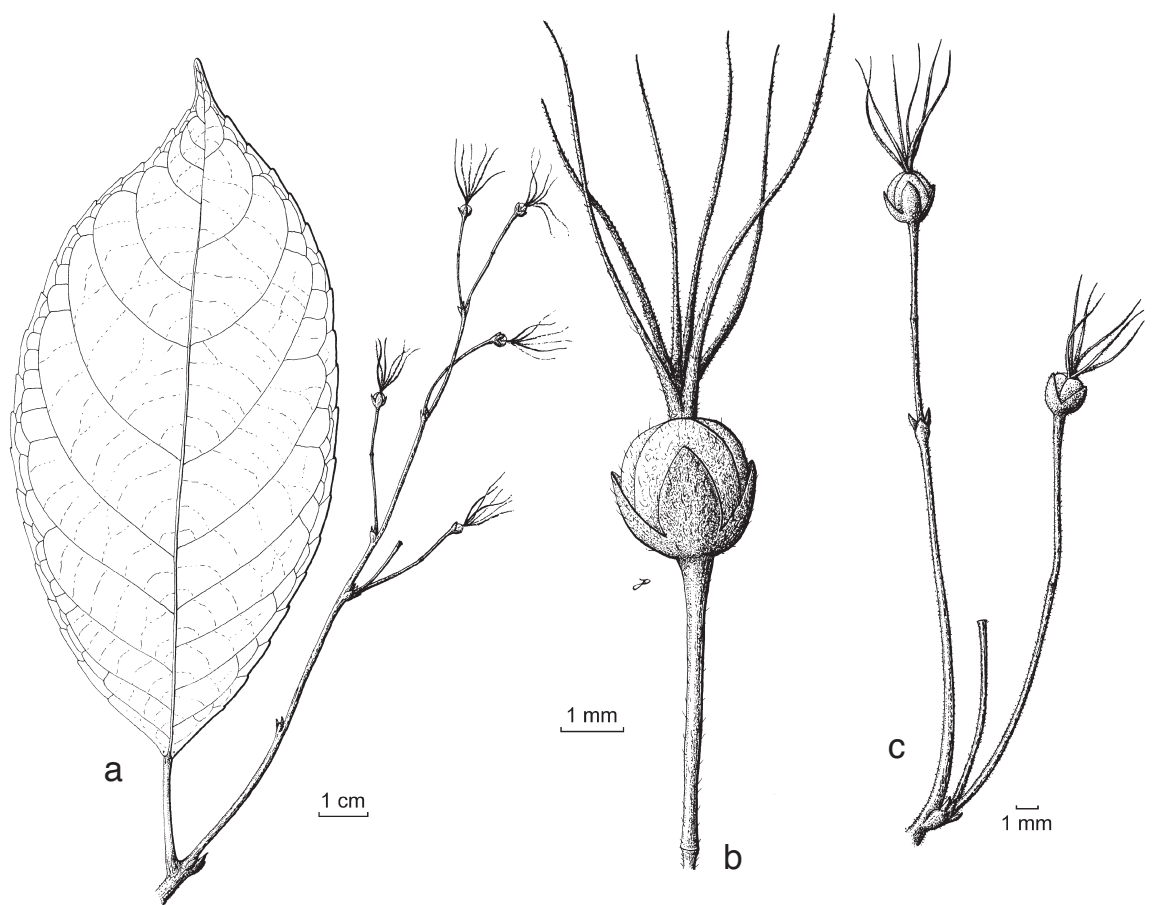

Fig. 5. Cleidion minahassae Pax \& K. Hoffm. a. Detail of leaf and pistillate inflorescence; b \& c. details on flower and pistillate inflorescence (a-c: Forsten 11 L 0158342, L).

\section{Cleidion moniliflorum Airy Shaw - Fig. 1c; Map 2}

Cleidion moniliflorum Airy Shaw (1980a) 591; (1980c) 58. - Cleidion javanicum Blume var. moniliflorum (Airy Shaw) Chakrab. \& M.G. Gangop. (1988b) 493. - Cleidion spiciflorum (Burm.f.) Merr. var. moniliflorum (Airy Shaw) Radcl.-Sm. \& Govaerts (1997) 478. - Type: NGF (Henty \& Frodin) 27334 (holo K; iso L), New Britain, Wariai subdist., Upper Pulie River, near Benim Village.

Tree, monoecious; flowering branches 3-9 $\mathrm{mm}$ (staminate) or c. $2 \mathrm{~mm}$ (pistillate) thick. Indumentum sericeous, vegetative parts (subglabrous to) sparsely hairy (except leaf blade), generative parts (subglabrous to) sparsely hairy; granulate surfaces present. Stipules $3-5$ by c. $1 \mathrm{~mm}$, caducous. Leaves inserted evenly along branches; petiole $0.5-2 \mathrm{~cm}$ long, apical glands absent; blade elliptic to some slightly obovate, $9-20$ by $3.5-6.5 \mathrm{~cm}$, length/width ratio $2.6-3.5$, base acute to cuneate (to slightly attenuate), margin (subentire to) finely serrate, teeth 19-29 per side, apex acuminate, very apex acute, upper surface (sub)glabrous, extra-floral nectaries absent, lower surface (subglabrous to) sparsely hairy only on midrib and nerves, domatia absent; nerves 11-14 per side. Staminate inflorescences ramiflorous, often 2 together, up to $50 \mathrm{~cm}$ long, basally c. $1 \mathrm{~mm}$ thick, flowers many per node, in glomerules; bracts c. 1 by $1 \mathrm{~mm}$. Staminate flowers: mature flowers not seen; buds dark brown to dark grey when dry, granulate; stamens c. 40. Pistillate inflorescences: only fragment of premature inflorescence seen, with at least 3 nodes. Pistillate flowers, fruits and seeds not seen. 
Distribution - Papua New Guinea: New Britain (only known from type locality). Habitat \& Ecology - Forest, undulating terrain. Altitude 120 m. Flowering: March.

Note - It is clearly erroneous to treat this species as a variety of $C$. javanicum (Chakrabarty \& Gangopadhyay, 1988b), because it differs from C. javanicum in several critical characters (hairs in vegetative parts present, surfaces granulate, staminate flowers in glomerulate clusters, pistillate inflorescences with several flowers).

\section{Cleidion papuanum Lauterb. - Fig. 6a-c; Map 4}

Cleidion papuanum Lauterb. in K. Schum. \& Lauterb. (1905) 296; Pax \& K. Hoffm. (1914) 293; Whitmore (1966) 173; Airy Shaw (1969) 85; (1980c) 58. - Type: Schlechter 14122 (holo WRSL; iso BM, BO, P), Kaiser-Wilhelmsland [= Papua New Guinea], Weg vom Ramu zur Küste.

Trigonostemon oliganthum K. Schum. in K. Schum. \& Lauterb. (1905) 298. - Type: Nyman 554 (UPS), Kaiser-Wilhelmsland [= Papua New Guinea], Sattelberg bei $800 \mathrm{~m}$.

Cleidion salomonis Airy Shaw (1969) 87. - Type: BSIP (Whitmore) 4233 (holo K; iso L), Solomon Islands, San Cristobal, Wairaha River, 5 miles from north coast. Syn.nov.

Shrub to small tree, usually few-branched, up to $5(-12) \mathrm{m}$ high, dbh up to $8 \mathrm{~cm}$; (mono- or) dioecious; flowering branches 1.5-10 mm thick. Bark yellow to brown to grey, smooth (to fissured). Indumentum sericeous to hirsute (erect or variably oriented), vegetative parts sparsely (to densely) hairy (except leaf blade), generative parts (subglabrous to) sparsely (to densely) hairy; granulate surfaces present. Stipules $4-45$ by $0.5-5 \mathrm{~mm}$, caducous to fairly persistent. Leaves well separated or \pm tightly grouped at the branch ends; petiole $0.4-2.5 \mathrm{~cm}$ long, apical glands absent; blade obovate, 9.8-73 by $2.5-17 \mathrm{~mm}$, length/width ratio $2.8-7.5$, base gradually narrowing, cuneate (to attenuate), margin (crenate to) serrate, basally often subentire, teeth $26-80$ per side, apex (obtuse to) acuminate, very apex (rounded to) acute to acuminate, upper surface glabrous to sparsely hairy on venation, lower surface (subglabrous to) sparsely hairy, hairs mainly on venation, domatia absent; nerves 11-34 per side. Staminate inflorescences up to $120 \mathrm{~cm}$ long, basally $0.75-4 \mathrm{~mm}$ thick, flowers many per node, in glomerules or often

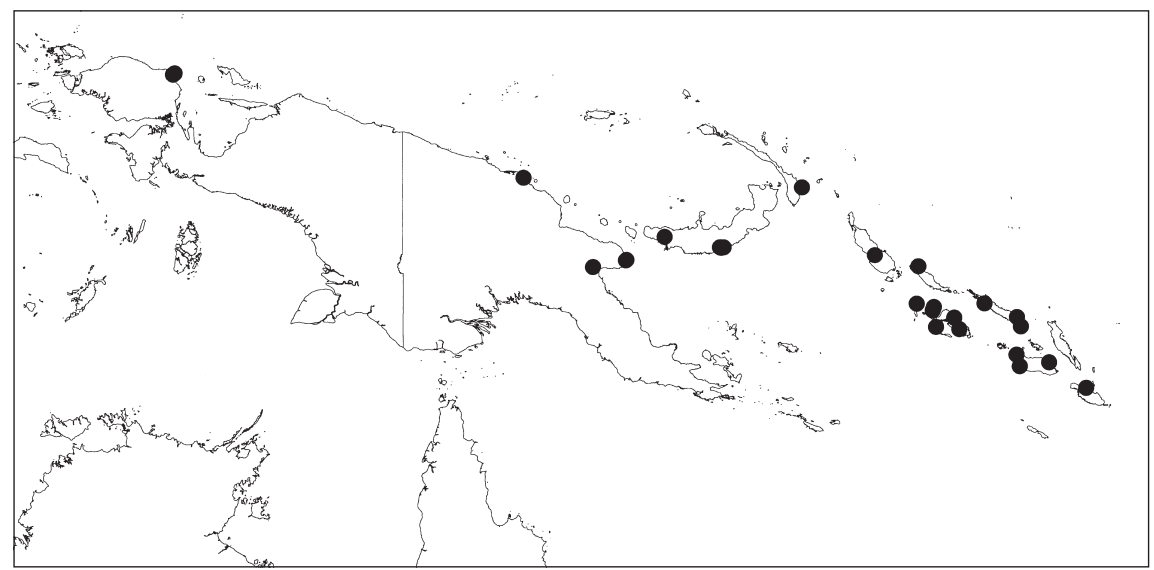

Map 4. Distribution of Cleidion papuanum Lauterb. 
slightly elongated, branching clusters; bracts $0.75-2$ by $0.5-1.5 \mathrm{~mm}$. Staminate flowers: pedicels up to $2.5 \mathrm{~mm}$ long; buds $1-1.5 \mathrm{~mm}$ diam., brown to dark grey when dry, without distinctly granulate surface; sepals c. 1.5 by $1 \mathrm{~mm}$; stamens $45-67$, filaments up to $1 \mathrm{~mm}$ long, anthers $0.3-0.5$ by $0.4-0.6 \mathrm{~mm}$, apiculum less than $0.1 \mathrm{~mm}$ long. Pistillate inflorescences $10-45 \mathrm{~cm}$ long, basally $0.75-2 \mathrm{~mm}$ thick, with 2-6(-16) nodes in upper half, 1(-3) flowers per node; bracts $1-4$ by $0.5-1.5 \mathrm{~mm}$, persistent. Pistillate flowers: pedicel 10-25 mm long, with abscission zone at the basal to apical part (1-22 mm from base); sepals 3, 1-4 by $0.5-1.5 \mathrm{~mm}$, persistent; locules 3 (or 4); style $0-1.5 \mathrm{~mm}$ long; stigmas erect to slightly ascending, 7-20 mm long. Fruits c. 6 by $10 \mathrm{~mm}$, readily opening, surface \pm smooth, green to cream to red when fresh, brown when dry. Seeds c. 6 by $5 \mathrm{~mm}$; hilum elliptic, c. 1 by $0.75 \mathrm{~mm}$.

Distribution - New Guinea, Solomon Islands.

Habitat \& Ecology - Primary (to secondary) rain forests, often on ridges and hillsides, well to poorly drained soils. Altitude up to $900 \mathrm{~m}$. Flowering and fruiting all year round.

Vernacular names - Papua New Guinea: Fokko (Manikiong). Solomon Islands: Sa'a, saola (Kwara'ae).

Note - Cleidion salomonis, a species with large leaves, is synonymised with C.papuanum. The type of the former represents one end of a continuum in a vast variation in leaf and stipule size. The specimens with small or large leaves are also geographically intermixed.
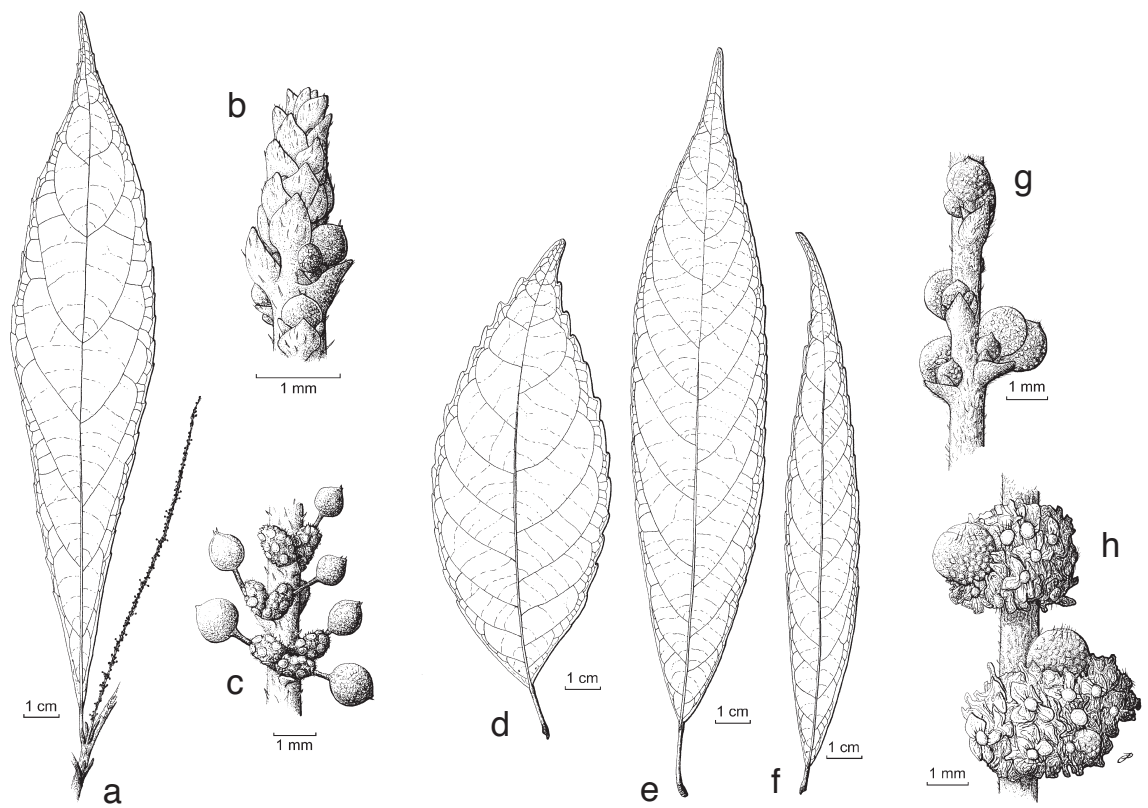

Fig. 6. Cleidion papuanum Lauterb. a. Detail of leaf and staminate inflorescence; b. detail of apex of staminate inflorescence; c. detail of older part of staminate inflorescence. - Cleidion ramosii (Merr.) Merr. d. Leaf of var. ramosii; e, f. leaves of var. lanceolatum (Merr.) Kulju; g. detail of young inflorescence; h. detail of old inflorescence (a-c: BSIP 7184; d, g, h: Coode 5432; e: Ramos 1648; f: $B S 43176$; all L). 
Diagnostic characters - Only Malesian species with always clearly obovate leaves and gradually narrowing leaf base.

\section{Cleidion ramosii (Merr.) Merr. - Fig. 6d-g; Map 3}

Cleidion ramosii (Merr.) Merr. (1922) 400; (1923) 439; Airy Shaw (1983) 13. - Mallotus ramosii Merr. (1912) 401; Pax \& K. Hoffm. (1914) 195. — Lectotype (selected here): BS (Ramos) 14602 (holo US; iso A, K), Philippines, Camiguin de Mindanao, near the summit of Mt Catarman.

Cleidion lanceolatum Merr. (1914) 474; Pax \& K. Hoffm. (1919) 23; Merr. (1923) 439; Airy Shaw (1983) 13. - Lectotype (selected here): Ramos 1648 (holo G; iso A, BM, L, NSW, NY), Philippines, Samar. Syn. nov.

Mallotus samarensis Merr. (1914) 488. - Type: BS (Ramos) 17480 (iso K, US), Philippines, Samar, Yabong.

Shrub to small tree, up to $8 \mathrm{~m}$ high, dbh up to $13 \mathrm{~cm}$, monoecious; flowering branches 1-3.5 mm thick. Indumentum sericeous, vegetative parts (subglabrous to) sparsely hairy (except leaf blade), generative parts (subglabrous to) sparsely hairy (ovary densely hairy); granulate surfaces present. Stipules $2.5-5$ by $1-2 \mathrm{~mm}$, caducous to somewhat persistent. Leaves inserted evenly along branches; petiole $0.8-8 \mathrm{~cm}$ long, apical glands absent; blade (ovate to) elliptic (to some slightly obovate), 7.8-23 by $1.4-9.3 \mathrm{~cm}$, length/width ratio 1.9-8.8, base (rounded to) acute to cuneate to attenuate, margin subentire (to crenate) to serrate, teeth 9-23 per side, apex acuminate, very apex truncate to acute, upper surface (sub)glabrous, lower surface (subglabrous to) sparsely hairy only on midrib and nerves, domatia absent; nerves (7-)8-14 per side. Staminate inflorescences up to $24 \mathrm{~cm}$ long, basally $0.5-1.25 \mathrm{~mm}$ thick, flowers many per node, in glomerules; bracts $1-2.5$ by $1-2 \mathrm{~mm}$. Staminate flowers: pedicels up to $3 \mathrm{~mm}$ long; buds 1.25-2 mm diam., dark brown to dark grey when dry, granulate; sepals c. 2 by $1.5 \mathrm{~mm}$; stamens $60-108$, filaments up to c. $1 \mathrm{~mm}$ long, anthers $0.2-0.4$ by $0.3-0.6 \mathrm{~mm}$, apiculum up to $0.1 \mathrm{~mm}$ long. Pistillate inflorescences $6-18(-27) \mathrm{cm}$ long, basally $0.5-0.75 \mathrm{~mm}$ thick, with $1-5$ nodes in upper half, 1 (or 2) flowers per node; bracts $1.25-2.5$ by $1-1.5 \mathrm{~mm}$, persistent. Pistillate flowers: pedicel 4-23 mm long, with abscission zone in basal part (1-9 mm from base); sepals $3-5,1.5-3$ by $0.5-1.5 \mathrm{~mm}$, usually distinctly granulate, persistent; locules 3 ; style absent to up to $0.5 \mathrm{~mm}$ long; stigmas erect to ascending, $4.5-13 \mathrm{~mm}$ long. Fruits $4-5$ by c. $8 \mathrm{~mm}$, readily opening, \pm smooth, brown when dry. Seeds $3-4.5$ by $3.5-4.5 \mathrm{~mm}$; hilum \pm elliptic, $0.5-1$ by $0.1-0.5 \mathrm{~mm}$.

Distribution - Philippines.

Habitat \& Ecology - Primary and secondary forests; often along rivers and on limestone. Altitude up to $470 \mathrm{~m}$. Flowering and fruiting all year round.

Note - Cleidion lanceolatum is treated here as a rheophytic variety of $C$. ramosii, leaf length/width ratio being the only unambiguous character to separate the taxa. Variety lanceolatum also tends to have somewhat longer stipules, bracts, pistillate pedicels, sepals and stigmas, but these measurements overlap with those of var. ramosii.

Diagnostic characters - See under C. microcarpum.

KEY TO THE VARIETIES

1a. Leaf length/width ratio $1.9-3 \ldots \ldots \ldots \ldots \ldots \ldots \ldots$ a. var. ramosii

b. Leaf length/width ratio $3.4-8.8 \ldots \ldots \ldots \ldots \ldots \ldots$ b. var. lanceolatum 


\section{a. var. ramosii}

(for nomenclature see $C$. ramosii and $M$. samarensis under the species)

Leaves: petiole 1-8 cm long; blade (ovate to) elliptic (to slightly obovate), 7.8-23 by $3.2-9.3 \mathrm{~cm}$, length/width ratio 1.9-3; nerves (7-)8-11 per side.

Distribution - Philippines (Mindoro, Tablas, Samar, Siargao, Mindanao).

b. var. lanceolatum (Merr.) Kulju, comb. \& stat. nov.

Cleidion lanceolatum Merr. Philipp. J. Sci., Bot. 9 (1914) 474; Pax \& K. Hoffm. (1919) 23; Merr. (1923) 439; Airy Shaw (1983) 13. - Lectotype (selected here): Ramos 1648 (holo G; iso A, BM, L, NSW, NY), Philippines, Samar.

Leaves: petiole $0.8-3 \mathrm{~cm}$ long; blade narrowly to linear elliptic, $9.5-19.8$ by $1.4-3.6$ $\mathrm{cm}$, length/width ratio 3.4-8.8; nerves 9-14 per side.

Distribution - Philippines (Samar, Bohol).

Habitat \& Ecology - Often along rivers.

\section{DOUBTFUL SPECIES}

\section{Cleidion megistophyllum (Quisumb. \& Merr.) Airy Shaw}

Cleidion megistophyllum (Quisumb. \& Merr.) Airy Shaw (1971) 528; (1983) 13. - Actephila megistophylla Quisumb. \& Merr. (1928) 158. - Lectotype (selected here): BS (Ramos \& Edaño) 45466 (holo A; iso K, NY, US), Philippines, Luzon, Tayabas Prov., Casiguran.

Indumentum on pistillate parts sericeous, (subglabrous to) sparsely hairy, leaves glabrous; granulate surfaces present. Stipules not seen. Leaves: petiole $2-3.5 \mathrm{~cm}$ long, thick; blade obovate, $115-155$ by $21-26 \mathrm{~cm}$, length/width ratio 4.4-7.4, base cuneate, margin finely serrate, teeth c. 40 per side, apex acute; upper and lower surfaces without extra-floral nectaries, domatia absent; nerves $40-45$ per side. Staminate inflorescences and flowers not seen. Pistillate flowers not seen. Infructescences c. $12 \mathrm{~cm}$ long, basally 3-4 mm thick, with 3-8 fruits, 1 flower per node; bracts c. $5 \mathrm{~mm}$ wide, caducous to persistent; pedicels 4-9 $\mathrm{cm}$ long, with 3-6 bracteoles at basal part, abscission zone absent; sepals 5, ovate to obovate, $3-6$ by $2.5-4 \mathrm{~mm}$, apex rounded to obtuse; within the sepals remnants of a darker coloured seemingly disc-like structure surrounding the column and splitting into 1-2 mm long segments. Fruits: not seen completely, presumably 3 -seeded, readily opening, \pm smooth, dark brown to dark grey when dry, speckled. Seeds $17-19$ by $17-19 \mathrm{~mm}$; hilum $1-2$ by $0.5-1 \mathrm{~mm}$.

Distribution - Philippines (Luzon).

Notes -1 . This species is known only from an incomplete type collection (including only leaves and remnants of infructescences and fruits). According to the original description (Quisumbing \& Merrill, 1928), it is an up to $4 \mathrm{~m}$ high shrub occurring in damp forests along streams at low altitudes.

2. The absence of both staminate and pistillate flowers makes it impossible to indisputably confirm the placement of this species in genus Cleidion. The absence of extra-floral nectaries on both leaf surfaces, the presence of disc-like remnants inside the pistillate sepals, and the unusually long (relative to infructescence size) pistillate pedicels are deviating characters from all other (Malesian) Cleidion species. 


\section{EXCLUDED SPECIES}

Acalypha spiciflora Burm.f. (1768) 203. - Cleidion spiciflorum (Burm.f.) Merr. (1917) 322, in obs., pro typo. - Type: Herb. Burman (holo G, n.v., photo seen) = Claoxylon sp. (indicated by Merrill's note accompanying the type).

\section{Cleidion bishnui Chakrab. \& M.G. Gangop. (1988a) 473 = Cleidiocarpon laurinum Airy Shaw}

\section{ACKNOWLEDGEMENTS}

We would like to thank the following institutes for sending their material on loan: A, B, BM, BO, BR, BRI, C, CAL, CANB, DD, E, F, FI, G, K, MO, NSW, NY, P, PNH, U, UC, UPS, US, W, WELT and WRSL. The referee is thanked for his constructive suggestions. Jan van Os, Anita Walsmit Sachs and Joanna Porck made the beautiful drawings. Jan Frits Veldkamp kindly provided nomenclatural help and the Latin translation. We also thank Soraya Sierra for testing the key.

\section{REFERENCES}

Airy Shaw, H.K. 1969. Notes on Malesian and other Asiatic Euphorbiaceae. Kew Bull. 23: 1-131. Airy Shaw, H.K. 1971. Notes on Malesian and other Asiatic Euphorbiaceae. Kew Bull. 25: 473553.

Airy Shaw, H.K. 1972. The Euphorbiaceae of Siam. Kew Bull. 26: 191-363.

Airy Shaw, H.K. 1975. The Euphorbiaceae of Borneo. Kew Bull., Addit. Ser. 4.

Airy Shaw, H.K. 1980a. New Euphorbiaceae from New Guinea. Kew Bull. 34: 591-606.

Airy Shaw, H.K. 1980b. A partial synopsis of the Euphorbiaceae-Platylobeae of Australia (excluding Phyllanthus, Euphorbia and Calycopeplus). Kew Bull. 35: 577-700.

Airy Shaw, H.K. 1980c. The Euphorbiaceae of New Guinea. Kew Bull., Addit. Ser. 8.

Airy Shaw, H.K. 1981. The Euphorbiaceae of Sumatra. Kew Bull. 36: 239-374.

Airy Shaw, H.K. 1982. The Euphorbiaceae of Central Malesia (Celebes, Moluccas, Lesser Sunda Is.). Kew Bull. 37: 1-40.

Airy Shaw, H.K. 1983. An alphabetical enumeration of the Euphorbiaceae of the Philippine islands. Royal Botanic Gardens, Kew.

Backer, C.A. \& R.C. Bakhuizen van den Brink Jr. 1964. Flora of Java 1. Noordhoff, Groningen.

Beddome, R.H. 1861. Contributions to the botany of southern India. Madras J. Lit. Sci. 2, 22: $70-71$.

Blume, C.L. 1825. Bijdragen tot de flora van Nederlandsch Indië, 12de stuk. Lands Drukkerij, Batavia.

Brandis, D. 1906. Indian trees. Constable \& Co., London.

Burkill, I.H. 1966. A dictionary of the economic products of the Malay Peninsula, repr., 1. Crown Agents for Overseas Governments and Administrations, London.

Burman, N.L. 1768. Flora Indica. Haak \& Schreuder, Leiden \& Amsterdam.

Casaretto, J. 1843. Novarum stirpium brasiliensium decades. Joannis Ferrandi, Genuae.

Chakrabarty, T. \& M. Gangopadhyay. 1988a. A new species of Cleidion Bl. (Euphorbiaceae) from Burma. J. Econ. Taxon. Bot. 12: 473-474.

Chakrabarty, T. \& M. Gangopadhyay. 1988b. Notes on some Asiatic Euphorbiaceae 2. J. Econ. Taxon. Bot. 12: 491-493.

Cooke, T. 1906. The flora of the presidency of Bombay 2, 3. Taylor \& Franchis, London.

Dalzell, N.A. 1851. Contributions to the botany of western India. Hooker's J. Bot. Kew Gard. Misc. 3: 229 .

Dalzell, N.A. \& A. Gibson. 1861. Bombay flora. Education Society’s Press, Byculla.

Gagnepain, F. 1926. Euphorbiaceae. In: M.H. Lecomte (ed.), Fl. Indo-Chine 5: 229-673. Masson \& Cie, Paris. 
Govaerts, R., D.G. Frodin \& A. Radcliffe-Smith. 2000. World checklist and bibliography of Euphorbiaceae, vol. 1. Royal Botanic Gardens, Kew.

Grierson, A.J.C. \& D. G. Long. 1987. Flora of Bhutan 1, 3. Royal Botanic Garden, Edinburgh.

Henderson, C.P. \& I.R. Hancock. 1988. A guide to the useful plants of Solomon Islands. Ministry of Agriculture and Lands, Honaira.

Hooker, J.D. 1885. Flora of British India 5. Reeve \& Co, London.

Kanjilal, U.N., P.C. Kanjilal, R.N. De \& A. Das. 1940. Flora of Assam. Prabasi Press, Calcutta.

Kiu, H.S., S. M. Hwang \& Y.T. Chang. 1996. Euphorbiaceae 2. Flora Reipubl. Popularis Sin. 44, 2. Science Press, Beijing.

Kurz, S. 1877. Forest flora of British Burma 2. Goverment printing, Calcutta.

McPherson, G. \& C. Tirel. 1987. Flore de la Nouvelle-Calédonie et Dépendances 14. Euphorbiacées 1. Muséum National d'Histoire Naturelle, Paris.

Merrill, E.D. 1912. Notes on Philippine Euphorbiaceae. Philipp. J. Sci., Bot. 7: 379-410.

Merrill, E.D. 1914. Notes on Philippine Euphorbiaceae, II. Philipp. J. Sci., Bot. 9: 461-493.

Merrill, E.D. 1917. An interpretation of Rumphius's Herbarium Amboinense. Bureau of Printing, Manila.

Merrill, E.D. 1922. New or noteworthy Philippine plants, XVII. Philipp. J. Sci. 20: 367-476.

Merrill, E.D. 1923. An enumeration of Philippine flowering plants 2. Bureau of Printing, Manila.

Merrill, E.D. 1926. Additions to our knowledge of the Philippine flora, III. Philipp. J. Sci. 30: 389-430.

Müller Argoviensis, J. 1865. Euphorbiaceae. Linnaea 34: 1-224.

Müller Argoviensis, J. 1866. Euphorbiaceae. In: A. de Candolle, Prodromus systematis universalis regni vegetabilis 15, 2: 189-1260. Masson \& Filii, Paris.

Pax, F. \& K. Hoffmann. 1914. Euphorbiaceae-Acalypheae-Mercurialinae. In: A. Engler (ed.), Das Pflanzenreich IV.147.vii. Engelmann, Leipzig \& Berlin.

Pax, F. \& K. Hoffmann. 1919. Euphorbiaceae - Additamentum VI. In: A. Engler (ed.), Das Pflanzenreich IV.147.xiv. Engelmann, Leipzig.

Pax, F. \& K. Hoffmann. 1931. Euphorbiaceae. In: A. Engler \& H. Harms (eds.), Die natürlichen Pflanzenfamilien ed. 2, 19C: 11-233. Engelmann, Leipzig.

Philcox, D. 1997. Euphorbiaceae. In: M.D. Dassanayake (ed.), A revised handbook to the flora of Ceylon. Balkema, Rotterdam.

Prain, D. 1963. Bengal plants 2. Botanical Survey of India, Calcutta.

Presl, C. 1845. Botanische Bemerkungen. Abh. Königl. Böhm. Ges. Wiss. 5, 3: 431-584.

Quisumbing, E. 1978. Medicinal plant of the Philippines. Katha Publishing Co., Quezon City.

Quisumbing, E. \& E.D. Merrill. 1928. New Philippine plants. Philipp. J. Sci. 37: 133-212.

Radcliffe-Smith, A. 2001. Genera Euphorbiacearum. Royal Botanic Gardens, Kew.

Radcliffe-Smith, A. \& R.H.A. Govaerts. 1997. New names and new combinations in the Euphorbiaceae-Acalyphoïdeae. Kew Bull. 52: 477-481.

Schumann, K. 1895. Plantae Bamlerianae. Notizbl. Königl. Bot. Gart. Berlin 2: 44-57.

Schumann, K. \& K. Lauterbach. 1905. Nachträge zur Flora der Deutschen Schutzgebiete in der Südsee. Gebrüder Borntraeger, Leipzig.

Takahashi, M., J.W. Nowicke, G.L. Webster, S. S. Orli \& S. Yanowski. 2000. Pollen morphology, exine structure, and systematics of Acalyphoideae (Euphorbiaceae). Part 3. Rev. Paleobot. Palynol. 110: 1-66.

Talbot, W.A. 1911. Forest flora of the Bombay presidency and Sind 2. Photozincographic Department, Poona.

Turczaninow, N. 1843. Decas generum plantarum hucusque non descriptorum. Bull. Soc. Imp. Nat. Moscou 16: 51-62.

Webster, G.L. 1994. Synopsis of the genera and suprageneric taxa of Euphorbiaceae. Ann. Missouri Bot. Gard. 81: 33-144.

Whitmore, T.C. 1966. Guide to the forests of the British Solomon Islands. Oxford University Press, London.

Whitmore, T.C. 1973. Tree flora of Malaya 2. Longman, London. 


\section{IDENTIFICATION LIST}

The numbers behind the collector numbers refer to the following taxa:
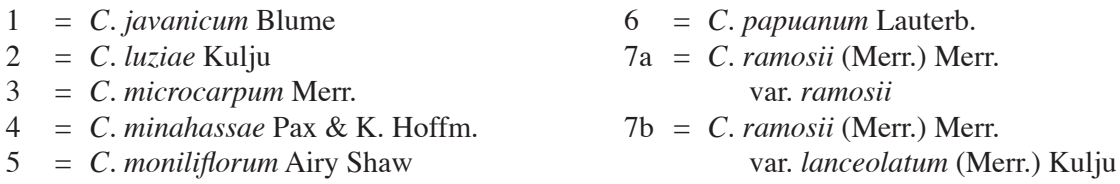

Adduru 244: 1 - Ahern 57: 1 - Averyanov VH 4709: 1.

Backer 4287: 1 - Baker 338: 1 - Bartlett 7173: 1; 8412: 1 - Batianoff \& Dillewaard 940560: 1 — bb series 2748: 1; 5929: 1; 15140: 1;21407: 1 - Becking 47: 1 - Bjørnland \& Schumacher 297: 1; 702: 1 - Blume 226: 1 - Bogor Botanical Garden IX.A.53: 1; IX.A.53a: 1; IX.A.58: 1; IX.A.58a: 1 - Brass 2980: 1; 3195: 2; 3276: 6 - BS series 7630: 1; 8021: 1; 13399: 1; 14151: 1; 14602: 7a; 15046: 1; 17480: 7a; 18311: 1; 27582: 1; 34172: 1; 35031: 7a; 39395: 7a; 39408: 7a; 41038: 1; 43176: 7b; 43701: 7b; 44226: 3; 46624: 1; 46847: 1; 75586: 1; 76913: 1; 77834: 1 - BSIP series 2825: 6; 3311: 6; 4233: 6; 4357: 6; 5564: 6; 6804: 6; 6892: 6; 7184: 6; 7187: 6; 7368: 6; 7744: 6; 8353: 6; 8590: 6; 9116: 6; 9692: 6; 9811: 6; 10377: 1; 12887: 1; 17926: 1; 18572: 6 - Burley \& Turkirin 2944: 1 - BW series 3514: 6; 3667: 1.

Champion 894: 1 - Chew Wee-Lek 333: 1; RSNH 183: 1; RSNH 311: 1 - Clarkson \& Neldner 10147: 1 - J. \& M.S. Clemens 16748: 1 - M.S. Clemens 314: 6; 1322: 6; 10491: 1; 10497: 1 - Collett 403: 1 - Collins 1233: 1 - Coode 5432: 7a; 5435: 7a - Cribb \& Wheatley 11: 1 - Cuming 1721: $7 \mathrm{~b}$ - Cumming 20528: 1 - Curry 788: 1; 1197: 1; 1475: 1.

Dali 189: 1 - Danimihardja SD 2169: 1.

Ebalo 505: 1 - Elbert 2483: 1 - Elmer 8142: 1; 8297: 1; 17615: 1.

FB series 2446: 1; 2664: 1; 3078: 1; 11992: 1; 14669: 1; 14849: 1; 20147: 1; 21560: 1; 21610: 1; 24083: 1; 24101: 1; 25685: 1; 26813: 1 - Fell 2246: 1; 4341: 1 - Fell \& Jensen 2472: 1 — Fernandes 1586: 1 - Ford \& Holmes 2580: 1 - Forster 5190: 1; 19474: 1 - Forster \& McDonald 8048: 1 - Fosberg 41551: 1.

Gardner 777: 1 - Garrett 1395: 1 - Gates 7159: 1 - Geesink, Hattink \& Phengklai 6703: 1 Geesink, Phanichapol \& Santisuk 5535: 1 - Geesink \& Phengklai 6141: 1 - Govers 94: 1.

Haenke 590: 1 - Halford Q 815: 1 - Halle RSNH 6307: 1 - Hansen \& Smitinand 12704: 1 - Hoogerwerf 215: 1 - Hoogland 5216: 1 - Horsfield 3: 1; 27: 1 - Hunt RSS 2620: 6 - Huq \& A.I. 10464: 1 - Huq \& Mia 10631: 1 - Hyland 1225: 1; 2556: 1; 2575: 1; 6270: 1; 6467: 1; 6998: 1; 7387: 1 .

Ja series 2055: 1; 3358: 1 - Jessup, Guymer \& Dillewaard 2840: 1 — Jessup, Guymer \& McDonald 1882: 1 .

Kajewski 2305: 2 - Kalshoven 88: 1; 1631: 1 - Kanis 1221: 2 - Kasin (Khwae Noi River Basin Expedition) 169: 1 - KEP FRI series 552: 1; 4240: 1; 15723: 1; 17884: 1 - Kerr 1040: 1; 1082: 1; 7396: 1; 9874: 1; 9963: 1; 10185: 1; 10298: 1; 12278: 1; 20013: 1; 20368: 1; 21088: 1; 21290: 1 - Koelz 33743: 1 - Koop 38: 1 - Koorders 1659: 1; 2067: 1; 2068: 1; 2071: 1; 2072: 1; 2073: 1; 2079: 1; 2082: 1; 2086: 1; 2090: 1; 2091: 1; 2093: 1; 2099: 1; 2100: 1; 2101: 1; 2102: 1; 2104: 1; 2105: 1; 2107: 1; 2108: 1; 2109: 1; 2306: 1; 2561: 1; 2730: 1; 12775: 1; 12797: ; 12798: 1 ; 12859: 1 ; 12984: 1 ; 12985 : 1 ; 13505: 1 ; 13754: 1 ; 13755: 1 ; 13756: 1 ; 16938 : 1 ; 20514: 1; 20518: 1; 20519: 1; 22795: 1; 22837: 1; 24571: 1; 24712: 1; 24882: 1; 25204: 1; 25303: 1; 28729: 1; 28909: 1; 28918: 1; 30134: 1; 30562: 1; 38507: 1; 38891: 1; 39774: 1 - Kostermans 2632: 6; 18687: 1; 19044: 1; 19270: 1 - Kostermans (Khwae Noi River Basin Expedition) 1140: 1 - Kostermans \& Wirawan 217: 1 - Kostermans et al. KK + SS 267: 1 - Koyama, Konta \& Nanakhorn T-49007: 1 - Kurz 1556: 1.

LAE series 61118: 1; 63071: 6; 74307: 1 - Larsen 9087: 1 - Larsen, Santisuk \& Warncke 2342: 1 - Larsen et al. 31564: 1 - Llanos 225: 1 - Lörzing 4056: 1; 13310: 1 .

Marcan 758: 1; 1183: 1 - Maxwell 75-91: 1; 88-755: 1; 89-12: 1; 89-538: 1; 89-755: 1; 91-137: 1; 91-454: 1;93-270: 1; 94-75: 1; 95-73: 1;95-111: 1;96-278: 1; 96-631: 1;96-900: 1 - McDonald 
\& Bean 5569: 1 - McDonald, Fell \& Stanton 4400: 1 - Meijer \& Noerta 9105: 1 - Merrill 2035: 1; 2045: 1; 2069: 1; Spec. Blanc. 532: 1 - Middleton et al. 422: 1 - Murata, Fukuoka \& Phengklai T-16620: 1.

Neldner \& Clarkson 3602: 1 - NGF series 1632: 1; 2639: 1; 3547: 1; 16435: 6; 21960: 6; 27334: 5; 27345: 6; 34404: 6; 37982: 6; 39145: 1; 41934: 1 - Nimanong 31: 1 - Nooteboom 1300: 1; 1302: 1 ; 1321: 1 - Nyman 554: 6.

O'Farrell 65: 1 .

Palee 53: 1 - Perry 1: 1; 2: 1 - Phengklai 17: 1 - Phengklai et al. 3071: 1 - PNH series 2908: 1; 6039: 7b; 6225: 7b; 9528: 1; 11829: 1; 16962: 7a; 17379: 1; 18640: 1; 23065: 1; 33383: 1; 33405: 1 ; 34124: 1 ; 34231: 1 ; 34311: 1 ; 34343: 1 ; 34355: 1 ; 35253: 1 ; 35457: $1 ; 35470: 1 ; 35490$ : 1; 36860: 3; 37302: 1; 39169: 1; 40312: 1; 40345: 1; 78162: 1; 80761: 3; 91330: 3; 91487: 3; 91567: 3; 97999: 1; 117103: 7b - Poilane 1630: 1; 6996: 1; 8969: 1; 14494: 1; 16535: 1; 18107: 1; 20256: 1; 20520: 1 - Pottier 135: 1 - PPI series 5765: 7b; 7382: 7b; 9339: 7a; 13453: 3; 15478: 1; 20278: 3; 20314: 3; 24103: 7b; 24584: 1; 24752: 1; 24753: 7a; 25119: 1; 25299: 1 - Prazer 49: 1 .

Rahmat si Toroes 68: 1; 4651: 1; 4731: 1;4951: 1;4964: 1 - Ramos 1648: 7b - Raynal RSNH 16413: 1 - Regalado \& Sirikolo 772: 6 - RFD series 3806: 1 - Ridsdale SMHI 127: 1 - Riswan, Afriastini \& Nurdin SR 35: 1.

S series 4637: 1; 21606: 1; 34188: 1; 39935: 1; 40199: 1 - SAN series 33345: 1; 66698: 1 - Sands 801: 6 - G. \& N. Sankowsky 759: 1 - Schlechter 14122: 6 - Schmutz 830: 1; 1703: 1; 1877: 1; 3029: 1; 3347: 1 - L.S. Smith 11707: 1 - Soejarto, Fernando \& Majaducon 9127: 1 - Soejarto \& Gaerlan 8286: 1 - Soejarto et al. 7975: 7b - Soepadmo 274: 1 - Sørensen, Larsen \& Hansen 2952: 1; 3076: 1 - Stone 9395: 1; 13735: 1 - Subramanian 1127: 1 - Suharno IRA 139: 2.

Talbot 1320: 1 - Thompson 150: 1 - Thwaites 656: 1; 2104: 1 - Toxopeus \& Saprin 293: 2.

Van Balgooy 7283: 1 - Van Beusekom \& Santisuk 2775: 1 - Veillon 4069: 1; RSNH 4506: 1 - Verheijen 2921: 1 - Vidal 1749b: 1; 1749c: 1; 3497: 1; 3714: 1.

Wang 77596: 1 - Warburg 12272: 1 - Waterhouse 79: 1; 331: 1; 886: 1 - Weber 8: 3 - Webster \& Bennett 19419: 1 - Webster \& Hyland 18887: 1 - Whitmore 3014: 1 - Whitmore \& Wardani 3365: 1 - Wight KD 2631: 1 - Williams 2716: 1 - Wirawan 427: 1 - Worthington 1258: 1; 1429: 1 ; 3207: $1 ; 3651: 1$

Yates 2244: 1 . 